\title{
Prolyl hydroxylase 2 dependent and Von-Hippel-Lindau independent degradation of Hypoxia-inducible factor 1 and 2 alpha by selenium in clear cell renal cell carcinoma leads to tumor growth inhibition
}

Sreenivasulu Chintala ${ }^{1,3^{*}}$, Tanbir Najrana ${ }^{1}$, Karoly Toth¹, Shousong Cao ${ }^{1,2}$, Farukh A Durrani ${ }^{1}$, Roberto Pili ${ }^{2}$ and Youcef M Rustum ${ }^{1}$

\begin{abstract}
Background: Clear cell renal cell carcinoma (ccRCC) accounts for more than $80 \%$ of the cases of renal cell carcinoma. In ccRCC deactivation of Von-Hippel-Lindau (VHL) gene contributes to the constitutive expression of hypoxia inducible factors 1 and 2 alpha (HIF-a), transcriptional regulators of several genes involved in tumor angiogenesis, glycolysis and drug resistance. We have demonstrated inhibition of HIF-1a by Se-

Methylselenocysteine (MSC) via stabilization of prolyl hydroxylases 2 and 3 (PHDs) and a significant therapeutic synergy when combined with chemotherapy. This study was initiated to investigate the expression of PHDs, HIF-a, and VEGF-A in selected solid cancers, the mechanism of HIF-a inhibition by MSC, and to document antitumor activity of MSC against human $\mathrm{CCRCC}$ xenografts.

Methods: Tissue microarrays of primary human cancer specimens (ccRCC, head \& neck and colon) were utilized to determine the incidence of PHD2/3, HIF-a, and VEGF-A by immunohistochemical methods. To investigate the mechanism(s) of HIF-a inhibition by MSC, VHL mutated cCRCC cells RC2 (HIF-1a positive), 786-0 (HIF-2a positive) and VHL wild type head \& neck cancer cells FaDu (HIF-1a) were utilized. PHD2 and VHL gene specific siRNA knockdown and inhibitors of PHD2 and proteasome were used to determine their role in the degradation of HIF-1a by MSC.

Results: We have demonstrated that ccRCC cells express low incidence of PHD2 (32\%), undetectable PHD3, high incidence of HIF-a (92\%), and low incidence of VEGF-A compared to head \& neck and colon cancers. This laboratory was the first to identify MSC as a highly effective inhibitor of constitutively expressed HIF-a in cCRCC tumors. MSC did not inhibit HIF-1a protein synthesis, but facilitated its degradation. The use of gene knockdown and specific inhibitors confirmed that the inhibition of HIF-1a was PHD2 and proteasome dependent and VHL independent. The effects of MSC treatment on HIF-a were associated with significant antitumor activity against cCRCC xenograft.
\end{abstract}

\footnotetext{
* Correspondence: sreenivasulu.chintala@roswellpark.org

'Department of Cancer Biology, Roswell Park Cancer Institute, Buffalo, NY

14263, USA

${ }^{3}$ Department of Pharmacology \& Therapeutics, Roswell Park Cancer Institute,

Buffalo, NY 14263, USA

Full list of author information is available at the end of the article
} 
Conclusions: Our results show the role of PHD2/3 in stable expression of HIF-a in human cCRCC. Furthermore, HIF-1a degradation by MSC is achieved through PHD2 dependent and VHL independent pathway which is unique for HIF-a regulation. These data provide the basis for combining MSC with currently used agents for cCRCC.

Keywords: Prolyl hydroxylases, Hypoxia-inducible factor, Clear cell renal cell carcinoma, Selenium

\section{Background}

Kidney cancer is associated with several gene mutations including Von-Hippel-Lindau (VHL), fumarate hydratase (FH) and succinate dehydrogenase (SDH) [1] and accounts for $3 \%$ of all cancers with $2 \%$ of the total cancer deaths in the U.S [2]. Among all kidney cancers, clear cell renal cell carcinoma (ccRCC) is the most common with a molecularly distinct phenotype [3] and contain up to $91 \%$ nonfunctional VHL mutations [1] which may leads to the constitutive expression of hypoxia inducible factors 1 and 2 alpha (HIF- $\alpha$ ). HIF- $\alpha$ are transcription factors that regulate several genes $(>100)$ involved in angiogenesis, cell proliferation, apoptosis, glycolysis, iron metabolism, drug resistance and other cellular processes to adapt to low oxygen hypoxic conditions in various solid tumors [4]. HIF- $\alpha$ are susceptible to oxygen dependent degradation under regular oxygenated conditions through the hydroxylation of proline molecules by prolyl hydroxylases (PHDs). There are four isoforms of PHDs (PHD1- 4) whose functions are different in various cellular systems $[5,6]$. Under regular oxygen conditions, HIF- $1 \alpha$ is hydroxylated at proline 402 and proline 564 molecules by prolyl hydroxylases 2 and 3 (PHD2/3) which is then recognized by VHL and further degraded by proteasome $[7,8]$. In general, PHD2 and PHD3 are expressed normally under normoxic conditions and their hydroxylation activity is inhibited under hypoxic conditions, resulting in the stable expression of HIF- $\alpha$ proteins [9]. The preferential hydroxylation of HIF- $1 \alpha$ by PHD2 and HIF-2 $\alpha$ by PHD3 has been reported [7]. Recent report, however, indicates that PHD2 and 3 hydroxylate HIF- $1 \alpha$ and HIF- $2 \alpha$ with similar efficiency [10]. The differences in cellular localization of PHD 2 and 3 have been reported, showing that PHD2 expression mostly in cytoplasm and PHD3 in cytoplasm and nucleus [11]. Recently, PHD3 mRNA deregulation has been reported in several cancers including renal, prostate, breast and melanoma [12]. PHD3 is not only involved in the hydroxylation of HIF- $\alpha$, but also has a role in apoptosis $[13,14]$.

Stable expression of HIF- $\alpha$ is regulated by synthesis and degradation pathways. It is likely that a lower level of HIF- $\alpha$ degradation pathway exists in ccRCC due to mutations in VHL. Several modulators of PHD activity have been implicated in HIF-stability. These include enhanced levels of reactive oxygen species (ROS) [15], nitric oxide [16,17], 2-oxoglutarate, Fe (II), ascorbate, fumarate and succinate [15]. Recent report by Finely et al., showed that decreased levels of SIRT 3, mitochondrial NAD-dependent deacetylase, resulted in increased cellular accumulation of ROS that contributes for the stability of HIF- $\alpha$ [18].

To date, significant advancement in treatment of ccRCC with VEGF targeted inhibitors, has provided a proof of principle that targeting HIF- $\alpha$, an upstream regulator of VEGF, may result in significant therapeutic benefits $[1,19,20]$. As an alternative to the development of HIF- $\alpha$ targeting agents, the approach to develop agents that promote the degradation of HIF- $\alpha$ through activation of PHDs may be more productive in alleviating HIF- $\alpha$ signaling pathways [10]. Since the PHDs are upstream regulators of HIF- $\alpha$ and their role in the degradation of HIF- $\alpha$ in ccRCC expressing mutant VHL has not been well investigated.

Selenium is an essential element extensively utilized in prevention clinical trials, but has thus far produced conflicting results [21]. It is likely that effectiveness of selenium is influenced by the selenium dose and types. While selenomethionine (SLM) is extensively utilized in prevention trials, Se-Methylselenocysteine (MSC) is under development and offers biological and pharmacological properties not common with SLM. Our laboratory was the first to report that optimal dose and schedule of MSC as highly effective inhibitor of ROS [22], nitric oxide [23], and HIF-1 $\alpha$ [22,23]. This inhibition was associated with anti-angiogenic effect and tumor vasculature maturation [24] leading to moderate antitumor (30\%) effect. Furthermore, remarkable therapeutic synergy was achieved in human tumor xenografts when optimal dose and schedule of MSC was used in sequential combination with anticancer drugs $[22,25]$. We have proved HIF- $1 \alpha$ as a critical target molecule for MSC effects demonstrating therapeutic synergy in HIF-1 $\alpha$ knockdown xenograft tumors with anticancer agent alone as comparable to MSC combination with anticancer agent [22]. HIF-1 $\alpha$ inhibition by siRNA also sensitized hypoxic human tumor cells to radiotherapy [26].

The current study was designed to a) investigate the incidence of PHD2/3, HIF- $\alpha$ in selected human solid cancers $b$ ) test the hypothesis that degradation of HIF- $\alpha$ by MSC is PHD2 and proteasome dependent, VHL and PHD3 independent and c) determine if these effects will 
translate into therapeutic benefit without toxicity in ccRCC tumor xenografts.

\section{Methods}

\section{Human primary tumors}

De-identified human primary tumors of ccRCC, head \& neck, and colon cancers separately arranged in Tissue microarrays (TMAs) (cores $6 \mathrm{~mm}$ in diameter)) and available frozen tissues of ccRCC tumors with their matched normal kidney were obtained from the Data Bank and BioRepository (DBBR) core facility, Department of Pathology, Roswell Park Cancer Institute, according to the institutional review board (IRB) approved protocols.

\section{Chemicals and antibodies}

Se-Methylselenocysteine (MSC) was obtained from Sigma-Aldrich (St. Louis, MO). Methylselenic acid (MSA), the active metabolite of MSC, was purchased from PharmaSe Inc., (Lubbock, TX). L- $\left[{ }^{35} \mathrm{~S}\right]$-Methionine purchased from PerkinElmer (Waltham MA). HIF-1 $\alpha$ antibody was procured from R \& D Systems (Minneapolis, MN) and Novus Biologicals (Littleton, CO). HIF- $2 \alpha$ antibody was purchased from Abcam (Cambridge, MA) and Novus Biologicals (Littleton, CO). PHD 2 antibody as procured from Novus Biologicals (Littleton, $\mathrm{CO}$ ) and PHD3 was obtained from Abcam (Cambridge, MA). Proteasome inhibitor MG132 was purchased from Calbiochem (La Jolla, CA). Protein synthesis inhibitor cycloheximide (CHX) was purchased from Sigma (St. Louis, MO). Prolyl hydroxylases inhibitor dimethyloxaloyl glycine (DMOG) was obtained from Frontier Scientific Inc., (Logan, UT).

\section{Immunohistochemical methods}

Human primary tumors and some normal tissues (10\% neutral buffered formalin fixed and paraffin embedded) arranged in TMAs (core size $0.6 \mathrm{~mm}$ in diameter) of ccRCC (number 88), head \& neck (number 210) and colorectal (number 65) were used to evaluate expression of HIF- $1 \alpha$ and PHD2 and 3 simultaneously in ccRCC and separately for the individual markers in head \& neck and colorectal cancers by the immunohistochemical method developed previously by our laboratory [27]. Briefly, paraffin sections ( $5 \mu \mathrm{m}$ thickness) were cut from TMA blocks and immunostained with automatic immunostainer for HIF-1 $\alpha$, PHD2 and PHD3. This is a well characterized, validated, and reliable immunohistochemical method utilizing a Catalyzed Signal Amplification (CAS) reagent that made HIF- $1 \alpha$ nucleus confined detection possible. HIF- $2 \alpha$ was detected with the same method using anti-HIF- $2 \alpha$ from Novus Biologicals (Littleton, CO) at a concentration of $0.5 \mu \mathrm{g} / \mathrm{ml}$. Vascular endothelial growth factor-A (VEGF-A) was immunostained according to the method described by us [22] as single staining. Well known positive, negative and isotype controls were included in all immunohistochemical studies. All immunohistochemical slides were reviewed by a board certified, experienced pathologist (K.T).

\section{Semiquantitative assessment of the immunostainings}

HIF- $1 \alpha$ and HIF- $2 \alpha$ immunostainings were considered specific if they were localized in the nuclei, while for PHD2 and PHD3 cytoplasmic staining were considered as specific. Staining intensity was categorized as: not detectable in any tumor cells or the specific staining in the majority of tumor cells was weak $(\mathrm{w})$, moderate $(\mathrm{m})$ or strong (s). Staining intensity in the cores were compared with the known strong positive controls and categorized accordingly. Since one core $(0.6 \mathrm{~mm}$ in diameter) of the TMA contains roughly 600 tumor cells (varies based on the size of stroma, necrosis, inflammatory cell infiltration, size of vessels etc.) the estimated $1 \%$ of the total tumor cell population (in general 5-6 tumor cells at least) was considered as positive. During the original reading of the TMA's the staining in the cores was estimated and categorized with a letter $(\mathrm{w}, \mathrm{m}, \mathrm{s})$ indicating the staining intensity and with a number which showed the distribution of the percentage of tumor cells stained positively like: s/100 meaning $100 \%$ of the tumor cell stained strongly for the marker. The raw data were tabulated, and based on that we have provided additional data to the result section in order to better characterize the overall staining.

\section{Cell culture and MSA treatment}

Clear cell renal cell carcinoma cells RC2 which express HIF- $1 \alpha$ only and 786-0 cells which express HIF-2 $\alpha$ [28] were utilized for the studies. RC2 cells were cultured in DMEM with glucose, $10 \%$ FBS, $1.0 \%$ PSN. 786-0 cells were cultured in RPMI-1640 with 10\% FBS and 1\% PSN. Head \& Neck cancer cells FaDu were purchased from American Type Culture Collection (Manassas, VA) and cultured in RPMI-1640 supplemented with 10\% FBS. Cells were regularly tested for Mycoplasma. Since the HIF- $1 \alpha$ was not expressing constitutively in $\mathrm{FaDu}$ cells, $0.5 \%$ oxygen hypoxic conditions were used with a hypoxia chamber (IN VIVO 400 Ruskinn Technology Ltd., Cincinnati, OH) to induce HIF- $1 \alpha$ as described earlier [22]. Cells were seeded in the tissue culture plates and allowed to grow to a confluence of $70 \%$, then treated with MSA at a dose of $1 \mu \mathrm{M}$ for $\mathrm{FaDu}, 10 \mu \mathrm{M}$ for RC2 and $8-10 \mu \mathrm{M}$ for $786-0$ and incubated for $8-24 \mathrm{~h}$. Untreated controls were maintained for comparison.

\section{Effect of MSA on cell growth}

Cells (400-600) were seeded in 96 well plates, allowed to grow overnight, and treated with various concentrations (3, 
5, 7 and $10 \mu \mathrm{M})$ of MSA for $24 \mathrm{~h}$. Untreated controls were maintained without treatment. Cells were washed with medium for 3 times to remove MSA, fresh medium was added and incubated at $37{ }^{\circ} \mathrm{C}$ incubator for $96 \mathrm{~h}$. Growth inhibition of cells was determined by sulforhodamine-B (SRB) assay as described previously [22]. Briefly, medium was taken out and cells were fixed with $10 \%$ trichloroacetic acid and left the plates at $4{ }^{\circ} \mathrm{C}$ for at least 2 hours. Plates were processed for washing and staining with SRB using automated plate washer. The unbound SRB stain was removed by washing and the stain bound to the cells was measured using plate reader (Bio Tek Instruments, model EL340, Winooski, VT) at $570 \mathrm{~nm}$. Percent growth inhibition was determined considering growth of untreated control cells as $100 \%$.

\section{Effect of MSA on HIF-1a protein synthesis and degradation}

To determine the MSA effect on HIF-1 $\alpha$ protein synthesis, FaDu cells were treated with known protein synthesis inhibitor cycloheximide (CHX) alone and in combination with MSA for $1-24 \mathrm{~h}$ under $0.5 \%$ hypoxic conditions because HIF-1 $\alpha$ degradation was observed after 18-24 h of MSA exposure in these cells. To investigate the half-life of HIF-1 $\alpha, \mathrm{RC} 2$ cells were treated with CHX for 2, 4 and $8 \mathrm{~h}$ time points and evaluated HIF- $1 \alpha$ inhibition in these cells. Further studies to evaluate the effect of MSA on HIF- $1 \alpha$ protein synthesis, RC2 cells were treated with $\mathrm{CHX}$ with and without MSA for $8 \mathrm{~h}$ because at this earliest time point we found pronounced HIF- $1 \alpha$ inhibition by MSA in RC2 cells. Total protein extracts were isolated and determined the HIF-1 $\alpha$ expression by western blot. To further determine MSA effects on total protein synthesis, RC2 cells were pulsed with ${ }^{35} \mathrm{~S}$-methionine for $1 \mathrm{~h}$ before the $5 \mathrm{~h}$ incubation with $10 \mu \mathrm{M}$ MSA or $5 \mu \mathrm{M} \mathrm{CHX}$ as described [29]. Total protein extracts $(20 \mu \mathrm{g})$ were used to determine the incorporated radiolabeled methionine by SDS polyacrylamide gel electrophoresis followed by autoradiography. Gel was stained with coomassie blue stain and showed as loading control.

Total ${ }^{35} \mathrm{~S}$-methionine incorporated in the proteins was also determined by counting the radioactivity present in the protein extracts using Beckman LS 6000 Scintillation Counter. Total number of counts was calculated in one milligram of protein and compared with untreated controls. To investigate the effect of MSA on proteasome mediated degradation of HIF- $1 \alpha$, FaDu cells were treated with MSA and proteasome inhibitor $\mathrm{N}-[$ (phenylmethoxy) carbonyl]-L-leucyl-N-[(1 $\quad$ S)-1-formyl-3-methylbutyl]-Lleucinamide, (MG132) alone and in combination, and the HIF-1 $\alpha$ protein level was determined by western blot analysis. The effect of MG132 on the degradation of HIF- $1 \alpha$ in RC2 cells was determined by treating cells with MSA and MG132 alone and in combination concurrently and pretreatment of MG132 $1 \mathrm{~h}$ before treating with MSA for $8 \mathrm{~h}$. Protein extracts were prepared from the cells and used for determining HIF-1 $\alpha$ expression by western blot.

\section{PHDs inhibition by dimethyloxallyl glycine (DMOG)}

PHDs activity inhibitor, DMOG was used to treat cells with and without MSA to determine the HIF-1 $\alpha$ degradation effects of MSA. FaDu which do not express HIF- $1 \alpha$ under normoxic culture conditions were treated separately with $0.5 \mathrm{mM}$ DMOG alone and in combination with MSA for 18-24 h. Cells were processed for extraction of protein and western blot was performed to measure the HIF- $1 \alpha$ levels. Similarly, RC2 cells which express HIF-1 $\alpha$ constitutively were treated with $0.5 \mathrm{mM}$ DMOG and $10 \mu \mathrm{M}$ MSA alone and in combination and determined the HIF- $1 \alpha$ levels in these cells.

\section{SiRNA transfection}

To determine the PHD2 role in the degradation of HIF$1 \alpha$ by MSA, RC2 cells expressing PHD2 were utilized to knockdown PHD2. To evaluate whether MSA is utilizing VHL independent pathway of degradation of HIF-1 $\alpha$, $\mathrm{FaDu}$ cells which express wild type VHL were used to knockdown VHL by siRNA. Since RC2 cells express mutated VHL we have used FaDu cells for VHL knockdown experiments. Validated Silencer sure siRNA for the egg-laying-defective nine 1 (EGLN1) gene for PHD2 protein was purchased from Ambion/Invitrogen (Carlsbad, CA). VHL SMART pool siRNA was purchased from Thermo Scientific (Lafayette, CO). Cells were allowed to grow overnight to reach $\sim 70-80 \%$ confluence and siRNA transfection was performed using a Lipofectamine 2000 transfection reagent as per the procedure described by the manufacturer (Invitrogen, Carlsbad, CA). Briefly 200-500nM of siRNA was used with Lipofectamine 2000 and transfected into the cells and incubated at $37{ }^{\circ} \mathrm{C}, 5 \% \mathrm{CO}_{2}$ for $24 \mathrm{~h}$. Cells were trypsinized and seeded onto new tissue culture dishes and allowed to grow for 24-48 h. Cells were treated with and without MSA for 18-24 $\mathrm{h}$ and processed for the extraction of protein to determine the VHL, PHD2 and HIF- $1 \alpha$ levels by western blot. Each experiment was repeated at least twice.

\section{Western blot analysis}

Western blot analysis was performed to determine the effect of MSA or MSC on HIF- $\alpha$, and PHDs as per the procedure described previously [22]. Briefly, after the treatments, cells were washed twice with PBS, scrapped with a cell scrapper, centrifuged and cell pellets were collected. Protein extracts were prepared from the cell pellets using the lysis buffer with protease inhibitors and 
brief sonication. Tumor xenografts and human primary tumor tissues were collected, and snap-frozen in liquid nitrogen. Protein extracts were prepared by homogenizing with a Polytron homogenizer in lysis buffer. Twenty to forty $\mu \mathrm{g}$ of protein was used to separate on high efficient Mini-Protean precast 4-20\% gradient gel (Bio-Rad) and transfer to the PVDF membrane. Primary antibodies for HIF- $1 \alpha$ (R and D systems 1:250/500 dilution), HIF-2 $\alpha$ (Abcam, 1:250/500 dilution) PHD2 (Novus Biologicals 1:5000 dilution), PHD3 (Abcam 1:500 dilution), and VHL (Cell Signaling 1:500 dilution) were used and incubated for $1 \mathrm{~h}$ at room temperature or overnight at $4{ }^{\circ} \mathrm{C}$. Respective HRP conjugated secondary antibodies were used and incubated for $1 \mathrm{~h}$. Proteins were detected using LumiLight PLUS western blotting kit (Roche, Indianapolis, IN) for HIF-1 $\alpha$, PHD2/3 and VHL and an ECL advance kit for HIF- $2 \alpha$.

\section{Vascular endothelial growth factor (VEGF) analysis by enzyme-linked immunosorbent assay (ELISA)}

RC2 and 786-0 cells were seeded in 6 well plates and allowed to grow overnight in a regular culture medium. The cell culture medium was aspirated and fresh medium was added with reduced serum (1\% FBS) and treated with MSA for $24 \mathrm{~h}$. Cell culture supernatants from untreated and MSA treated cells were collected, centrifuged and immediately used for measuring secreted VEGF using a Quantikine Human VEGF Immunoassay kit as per the manufacturer's instructions ( $R$ \& D Systems, Minneapolis, MN). Briefly, $50 \mu \mathrm{l}$ of Assay Diluent was added to each well. Plate layout was marked with standard, control and experiment and $200 \mu \mathrm{l}$ of VEGF standard, cell culture supernatants of control and experiment were added and incubated for $2 \mathrm{~h}$ at room temperature. Each well was aspirated and washed 3 times with wash buffer and $200 \mu \mathrm{l}$ of VEGF conjugate was added and incubated for $2 \mathrm{~h}$ at room temperature. Aspiration and washing was repeated 3 times and $200 \mu \mathrm{l}$ substrate solution was added to each well, the plate was protected from light and incubated for $20 \mathrm{~min}$ at room temperature. Reaction was stopped by adding $50 \mu \mathrm{l}$ stop solution and mixing the plate gently, optical density was recorded at $450 \mathrm{~nm}$ using a microplate reader with correction at $540 \mathrm{~nm}$. The concentration of secreted VEGF was calculated using the standard curve created by plotting the mean absorbance on $y$-axis against the concentration on the $\mathrm{x}$-axis.

\section{RT-PCR analysis}

The expression of HIF- $1 \alpha$ and PHD2/3 were determined by quantitative real time PCR (pRT-PCR) analysis as per the methods described earlier [30] Total RNA was isolated from ccRCC cells and primary tumor tissues with matched adjacent normal kidney using the TRIzol method
(Invitrogen, Carlsbad, CA). Complementary DNA (cDNA) was synthesized from total RNA using a Superscript Firststrand synthesis kit according to the manufacturer's instructions (Invitrogen, Carlsbad, CA). For quantitative analysis of expression of HIF- $1 \alpha$ and PHD2/3, qRT-PCR was performed with SYBR green quantitative PCR technique using the Applied Biosystems Real-Time Cycler HT-7900. Expression levels were normalized to $\beta$-actin mRNA levels by calculating delta cycle thresholds $(\Delta \mathrm{Ct})$ $(\Delta \mathrm{Ct}=\mathrm{Ct}$ of the gene (HIF-1 $\alpha$, PHD2/3) $-\mathrm{Ct}$ of $\beta$-actin). Relative mRNA expression for each gene was normalized to control normal kidney tissues by using 2delta-delta CT method as described by manufacturer (Applied Biosystems). For determining the expression of genes in ccRCC cells the average delta $\mathrm{CT}$ values normalized to endogenous $\beta$-actin control were used to show the expression levels of genes in each cell line. Experiments were performed with replicate samples.

\section{Nude mice}

Female athymic NUDE-Foxn1 (nu/nu) mice, 8-12 weeks old (weight 20-25 g) were purchased from Harlan SpragueDawley Inc., (Indianapolis, IN). Mice were kept five per cage with water and food ad libitum according to the protocols approved by the Institute Animal Care and Use Committee (IACUC) at Roswell Park Cancer Institute.

\section{Tumor measurement and antitumor activity}

Vernier Caliper was used to measure the two axis (mm) of tumor (L, longest axis; W, shortest axis). The weight of the tumor was estimated using the formula: tumor weight $=1 / 2\left(\mathrm{~L} \times \mathrm{W}^{2}\right)$. Tumor measurements were taken daily for the first 8 days and at least 3 times each week for the following 2 weeks. Antitumor activity of selenium was determined by assessing the tumor size. Animals were sacrificed when the tumor weight reached $\sim 2$ grams according to the Institute's approved animal protocols.

\section{Statistical analysis}

Statistical analysis was performed using GraphPad Prism Software Inc. (La Jolla, CA). Standard Student's $t$-test was used to determine the significance between untreated control and selenium treatments and $\mathrm{p}<0.05$ was considered as significant. To determine whether the incidence of PHD2/3, HIF- $\alpha$ and VEGF in ccRCC is significantly different from head \& neck and colon cancer, the data was analyzed by Dr. Austin Miller (Senior Biostatistician, Department of Biostatistics, at Roswell Park Cancer Institute). Estimates and 95 percent confidence limits for the proportion of tissue sample with positive expression were calculated using Wilson Point Estimation methods [31]. Statistical significance for the difference in expression was assessed using Fishers Exact test. 
This test provides a measure of evidence supporting the null hypothesis of no difference in expression in a given marker between the disease groups (compared to ccRCC).

\section{Results \\ Low incidence of PHD2 and VEGF-A, undetectable PHD3, and high incidence of HIF- $a$, in human cCRCC tumors compared to head \& neck and colon cancers}

To determine the potential clinical relevance of the expression of PHD 2/3, HIF- $\alpha$ and VEGF-A proteins and their modulation by therapeutic doses of MSC, we have evaluated their incidence, intensity and cellular distribution in ccRCC $(n=88)$, head \& neck $(n=210)$, and colorectal $(n=65)$ human primary cancer specimens. Cancer specimens arranged in TMA were utilized to evaluate the markers simultaneously in the same cells by double immunohistochemical methods for HIF- $\alpha$ and PHD2 or PHD3 as described earlier [27]. As shown in Figure 1A and $1 \mathrm{~B}$, specific nuclear staining of HIF- $1 \alpha$ and HIF- $2 \alpha$ (arrows, brown) and cytoplasmic PHD2 (middle panel, pink) were found in ccRCC samples. PHD3 protein was undetectable (lower panel) in all 88 tumors. The percent incidence of these markers presented in Figure $1 \mathrm{C}$ shows $35 \%$ PHD2, no detectable PHD3, 92\% of HIF- $\alpha$ (HIF- $1 \alpha$ and/or HIF- $2 \alpha$ ), and $56 \%$ of VEGF-A in 88 cases of ccRCC. Some of the HIF- $1 \alpha$ positive tumors were also positive for HIF- $2 \alpha$ and vice versa for HIF- $2 \alpha$ expressing tumor. Tumors positive for HIF- $2 \alpha$ were excluded to determine exclusively HIF- $1 \alpha$ incidence and vice versa for HIF- $2 \alpha$ incidence. The data presented in Figure 1D show that the incidence of HIF- $1 \alpha$ only (9\%) was significantly low compared to HIF- $2 \alpha$ only (47\%) and co-expression of HIF- $1 \alpha$ and HIF-2 $\alpha$ (32\%) in ccRCC. In most cases, the nuclear staining intensity was strong for both HIF$1 \alpha$ and HIF-2 $\alpha$. Cytoplasmic staining was weak for PHD2 and VEGF-A. The data in Figure 1A-D demonstrated that the overall incidence and protein expression of HIF- $2 \alpha$ were dominant compared to HIF- $1 \alpha$ in cCRCC tumors.

HIF- $1 \alpha$ staining intensity was strong in all samples of ccRCC, and the average distribution was 66\% (in 13 cases even all tumor cells nuclei expressed HIF-1 $\alpha$ ) but the incidence (presence) of HIF-1 $\alpha$ alone was $9 \%$. This $9 \%$ was significantly lower than HIF-2 $\alpha$ alone (47\%). In head \& neck and colorectal cancers HIF- $1 \alpha$ staining was less intense (weak to moderate intensity) and involved in smaller areas. HIF- $2 \alpha$ distribution in ccRCC, head \& neck, and colorectal cancer are $15 \%, 5 \%$, and $11 \%$ respectively, meaning relatively few tumor cells express HIF- $2 \alpha$ in positive cases. Incidence of HIF- $2 \alpha$ only in ccRCC is relatively high $(46 \%)$ but in these positive samples, generally few tumor cell nuclei (15\%) express HIF-2 $\alpha$. The average distribution of PHD2 in ccRCC was $64 \%$ with weak intensity, while in head \& neck and colorectal cancers PHD2 was expressed very uniformly, almost in all tumor cells $(98 \%$ and $95 \%$ average distribution) with variable staining intensity (from weak to strong). PHD3 was not detectable in any sample of ccRCC. In contrast to ccRCC, in head \& neck and colorectal cancers, the majority of tumor cells (84\% and 78\% respectively) express PHD3 from weak to moderate intensity.

Head \& neck and colon cancers have significantly high incidence of PHD2 (86\% in head \& neck, and $83 \%$ in colon) and PHD3 (21\% in head \& neck, and 50\% in colon), and low incidence of HIF- $\alpha$ (38\% in head \& neck, and $27 \%$ in colon) (Figure 1C) compared to ccRCC. Despite the low incidence of HIF- $\alpha$, the incidence of VEGFA was found to be $79 \%$ and $97 \%$ in head \& neck and colon tumors, respectively (Figure $1 C$ ). Determination of HIF- $1 \alpha$ only, HIF- $2 \alpha$ only, and co-expression of HIF- $1 \alpha$ \& HIF- $2 \alpha$ revealed that the incidence of HIF- $1 \alpha$ only was high $(20 \%)$ in head \& neck cancer compared to colon (11\%) and ccRCC (9\%), whereas HIF- $2 \alpha$ only incidence was low in head \& neck (17\%) and colon (16\%) cancers compared to ccRCC (47\%). The co-expression incidence of HIF- $1 \alpha$ and HIF- $2 \alpha$ was very low in head \& neck $(2 \%)$ and colon (3\%) cancers compared to ccRCC (32\%) (Figure 1D). Collectively, these data suggest that an inverse relationship trend between HIF- $\alpha$ incidence and PHDs expression in ccRCC, head \& neck and colon cancers. Furthermore, the findings also revealed high incidence of HIF- $2 \alpha$ and co-expression of HIF- $1 \alpha$ and HIF- $2 \alpha$ in ccRCC compared to head \& neck and colon cancers. The data presented in Table 1 is a tabulation of the incidence ratio of HIF- $1 \alpha$, HIF- $2 \alpha$ to PHD2 and PHD3. The data indicate that the ratios of HIF- $\alpha$ to PHD2 in ccRCC were approximately 5-17 fold higher than that of head \& neck and colon tumors.

\section{CCRCC cell lines express similar HIF- $a$ and PHDs profiles as in clinical samples}

Since PHD3 protein was undetectable in 88 ccRCC tumors (Figure $1 \mathrm{~A}$ and $\mathrm{C}$ ), we have investigated the expression of PHD 2/3 mRNA and protein in selected clinical samples and ccRCC cell lines. The data in Figure 2A show the expression of PHD2, 3 and HIF- $1 \alpha$ mRNA in primary tumors. Quantitative real time RT-PCR (qRTPCR) analysis revealed the normal expression of HIF-1 $\alpha$, PHD2 and significantly high expression of PHD3 mRNA (3 out of 4 ) in primary tumors compared to their matched normal kidney (Figure 2A). There was variability in the expression of these markers among the tumors. In accordance with the clinical samples, the ccRCC cell lines $\mathrm{RC} 2$ and 786-0 expresses mRNA of HIF- $1 \alpha$ and PHD2/3 (Figure 2B). Like in primary tumor tissues there was a difference in the expression levels of these genes in the two cells lines. However, PHD3 


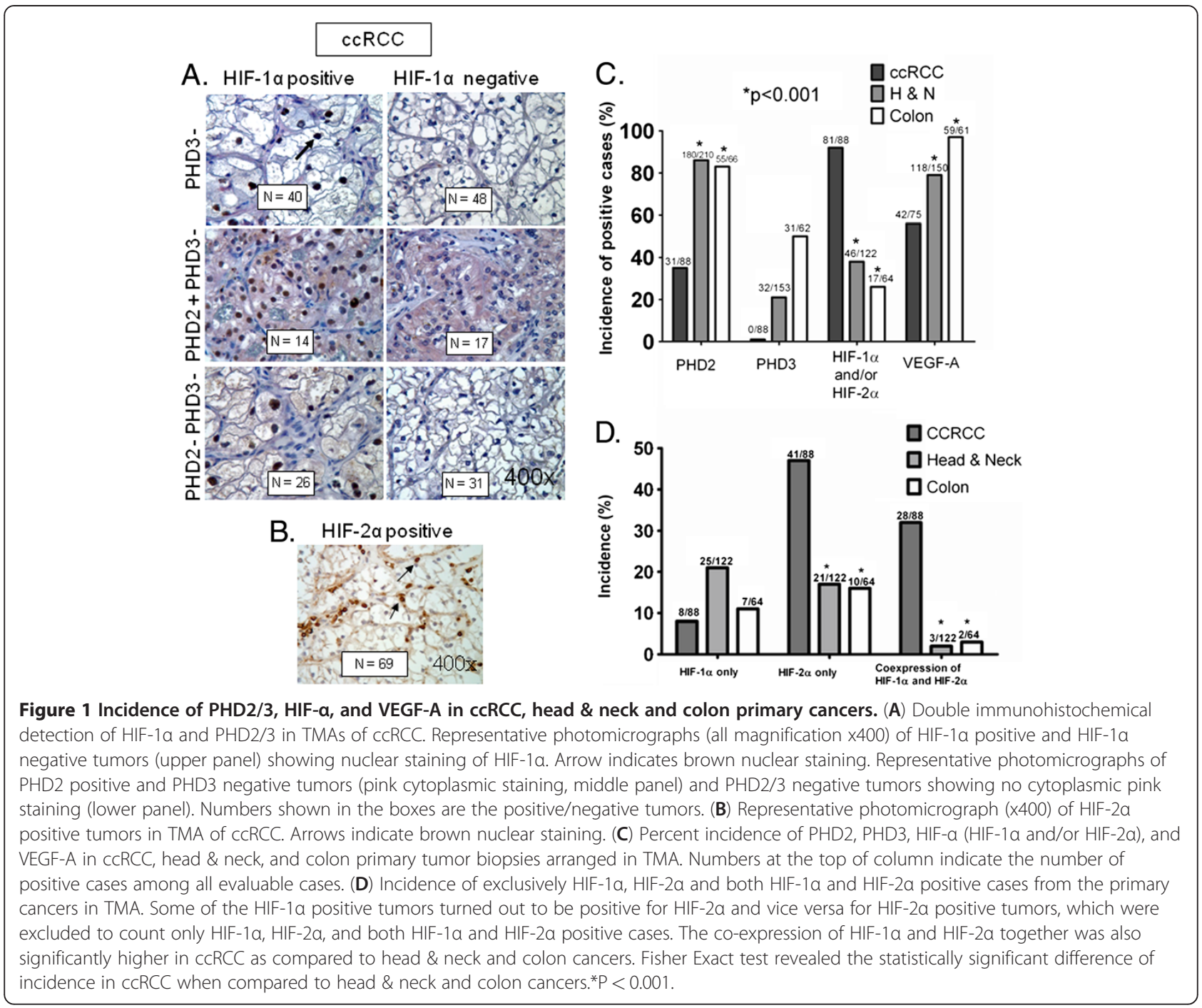

protein was undetectable in 88 tumor tissues by immunohistochemistry (Figure 1C) and in two cell lines (Figure 2D). A very weak expression of PHD3 was found by western blot analysis in tumor tissues (Figure 2C), likely derived from stromal cells since the whole tumor extract was used to do western blot analysis. The ccRCC cells RC2 and 786-0 used to determine mechanism of HIF- $1 \alpha$ regulation by PHDs have similar molecular profile like clinical samples expressing PHD2 protein and deficient in PHD3 protein but not mRNA (Figure 2B and D).

\section{Inhibition of HIF-1 $\alpha$ and HIF-2 $a$ by MSA does not translate into comparable downregulation of secreted VEGF, but inhibit the growth of cells}

The data presented in Figure 3 demonstrated that treatment with a pharmacological dose of MSA $(10 \mu \mathrm{M})$ the active metabolite of MSC, resulted in the inhibition of constitutively expressed HIF- $1 \alpha$ and HIF- $2 \alpha$ in RC2 and
786-0 cells, respectively (Figure 3A). The observed effective inhibition of HIF- $\alpha$ was associated with significant downregulation of secreted VEGF in RC2 cells expressing HIF- $1 \alpha$ but not in 786-0 cells expressing HIF- $2 \alpha$ (Figure 3B). The data in Figure 3B also indicate that HIF- $2 \alpha$ expressing 786-0 cells secreted significantly less VEGF than HIF- $1 \alpha$ expressing RC2 cells which might explain the lack of down-regulation of secreted VEGF by MSA. However, under hypoxic conditions, when the secreted VEGF was higher than normoxic conditions, MSA decreased the secreted VEGF levels (data not shown). Irrespective of VEGF levels, inhibition of HIF- $\alpha$ by MSA was associated with significant growth inhibition of RC2 and 786-0 cells (Figure 3C). The results in $\mathrm{RC} 2$ cells expressing HIF- $1 \alpha$ are consistent with our previous findings of HIF- $1 \alpha$ inhibition by MSA resulted in the downregulation of VEGF and growth inhibition in head \& neck tumors [22]. The data in Figure 3D shows the VHL restoration degraded HIF- $1 \alpha$ 


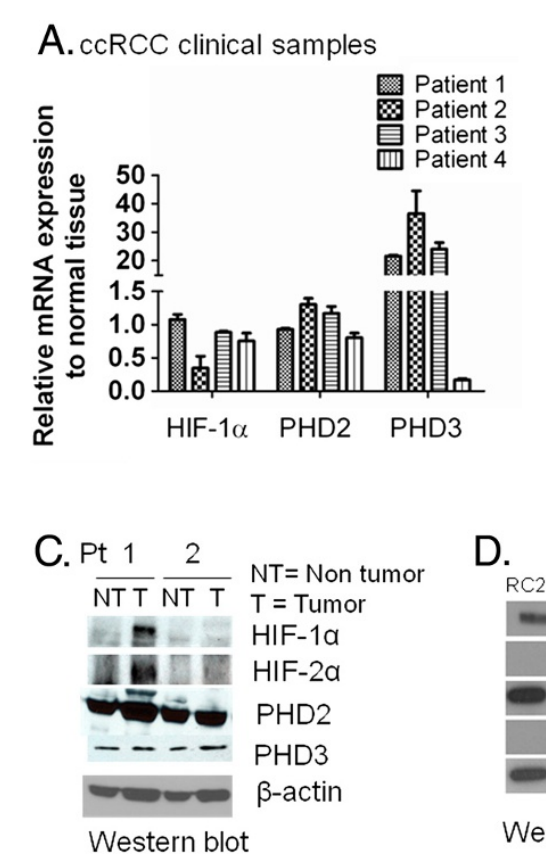

B. ccRCC cells

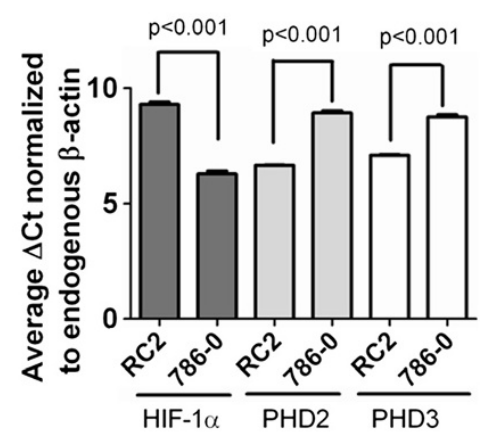

D.

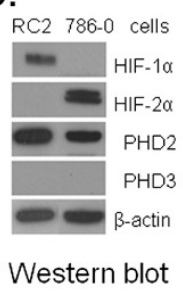

Figure 2 Expression of HIF-a, PHD2, and PHD3 mRNA and protein in ccRCC clinical specimens and cell lines. (A) Quantitative analysis of HIF-1a, PHD2, and PHD3 mRNA by real-time RT-PCR (qRT-PCR) in CCRCC primary tumors. Expressions were normalized to the matched normal kidney tissue by calculating ${ }^{2 \text { delta-deltact }}$ values relative to normal kidney reference. Expression of mRNA in individual tumors was shown. $\mathbf{B}$. Expression analysis of HIF-1a, PHD2, and PHD3 in cCRCC cells RC2 and 786-0. Expression was normalized to endogenous $\beta$-actin by calculating delta cycle threshold $(\Delta \mathrm{Ct}) . \Delta \mathrm{Ct}=\mathrm{Ct}$ value of specific gene (HIF-1a, PHD2 and PHD3) - Ct value of $\beta$-actin. The lower the $\Delta \mathrm{Ct}$ value the higher the expression of the gene. Experiment was repeated twice with triplicates and $p<0.05$ was considered as significant $P<0.001$. (C) Detection of HIF-1a, HIF-2a and PHD2/3 in cCRCC primary tumors and their matched normal kidney tissues by western blot analysis. 80 micrograms of protein extract was electrophoresed through Mini-Protean precast 4-20\% gradient gel. Expression of $\beta$-actin was used as a loading control. (D) PHD3 protein was undetectable in cCRCC cells. Detection of HIF- $\alpha$ and PHD2/3 by western blot analysis in ccRCC cells RC2 and 786-0 cells. $\beta$-actin expression was used as a loading control.

in RC2VHL cells but did not alter the sensitivity for MSA under aerobic culture conditions.

\section{MSA inhibits HIF-1a through post-translational degradation}

Three approaches were used to determine whether inhibition of HIF- $1 \alpha$ by MSA is at transcriptional or posttranslational modification: I) Time dependent inhibition of HIF- $1 \alpha$ protein synthesis by MSA was compared to a known protein synthesis inhibitor, cycloheximide ( $\mathrm{CHX})$; II) Determine MSA effect on incorporation of ${ }^{35} \mathrm{~S}-\mathrm{Me}$ thionine in protein synthesis, III) Evaluate the effect of a proteasome inhibitor, MG132 alone and in combination

Table 1 Ratio of HIF- $a$ to PHDs incidence in solid tumor specimens

\begin{tabular}{|c|c|c|c|c|}
\hline \multicolumn{5}{|c|}{ Incidence ratio $^{@}$} \\
\hline & HIF-1a/PHD2 & HIF-1a/PHD3 & HIF-2a/PHD2 & HIF-2a/PHD3 \\
\hline cCRCC & $1.29^{*}$ & - & $2.22^{*}$ & - \\
\hline$H \& N$ & 0.22 & 1.25 & 0.13 & 0.72 \\
\hline Colorectal & 0.15 & 0.26 & 0.18 & 0.32 \\
\hline
\end{tabular}

${ }^{\circledR}$ Incidence ratio was calculated by dividing incidence of HIF-a by the incidence of PHD2 or PHD3. ${ }^{*} \mathrm{P}<0.01$. with MSA on HIF-1 $\alpha$ degradation. The results presented in Figure 4A show that HIF- $1 \alpha$ protein synthesis was inhibited by $\mathrm{CHX}$ but not by MSA alone in $\mathrm{FaDu}$ cells indicating that HIF-1 $\alpha$ protein synthesis was not affected by MSA. In RC2 cells CHX inhibited protein synthesis at $4 \mathrm{~h}$ (data not shown) and $8 \mathrm{~h}$ (Figure $4 \mathrm{~B}$ ). There was some inhibition of HIF- $1 \alpha$ with MSA alone at $8 \mathrm{~h}$ treatment point which may be due to degradation (Figure 4B). To evaluate precisely whether MSA is inhibiting protein synthesis we have investigated the radiolabeled amino acid incorporation studies with ${ }^{35} \mathrm{~S}$-Methionine, and compared with known protein synthesis inhibitor $\mathrm{CHX}$. The results presented in Figure $4 \mathrm{C}$ and D clearly shows that MSA did not inhibit the protein synthesis at $5 \mathrm{~h}$ time point in $\mathrm{RC} 2$ cells. These results suggest that MSA may inhibit HIF- $1 \alpha$ through degradation pathway. To determine whether the selenium mediated degradation of HIF-1 $\alpha$ was proteasome dependent, $\mathrm{FaDu}$ and RC2 cells were treated with proteasome inhibitor MG132 alone and in combination with MSA and results are shown in Figure 4E and F. The results indicate that while MSA treatment resulted in significant inhibition of HIF-1 $\alpha$, the inhibition of proteasome by MG132 resulted 

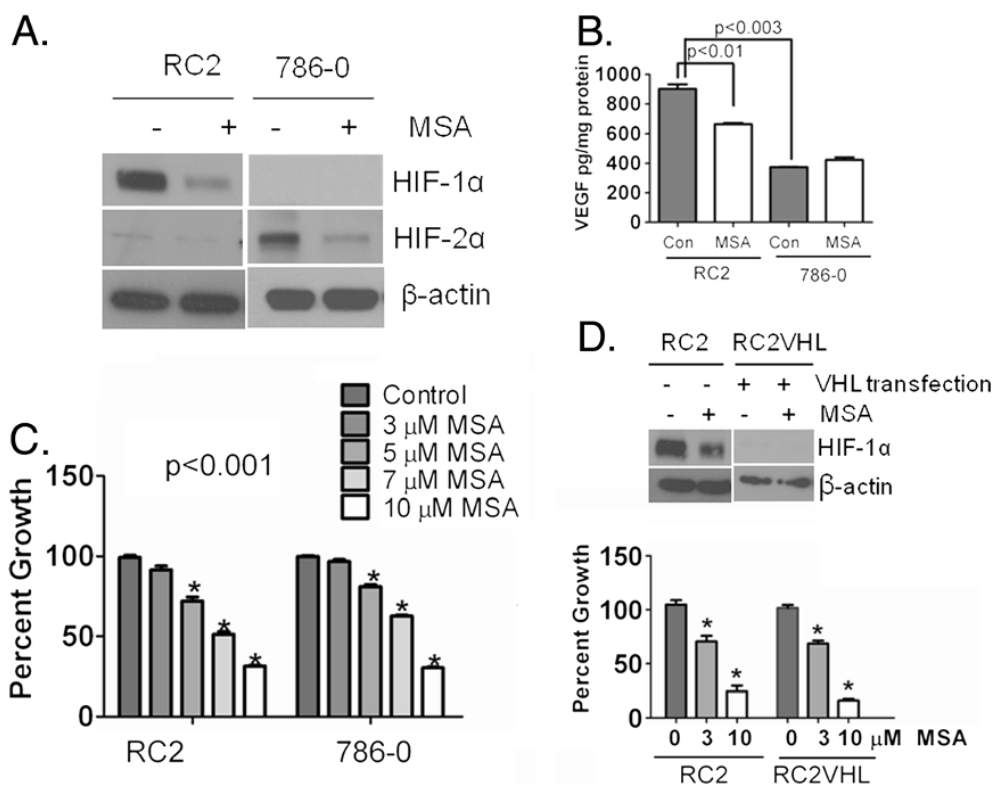

Figure 3 Effect of selenium treatment on HIF-1a, HIF-2a, VEGF and cell growth. (A) MSA inhibits both HIF-1a and HIF-2a. RC2 cells expressing HIF-1a and 786-0 cells expressing HIF-2a were treated with and without $10 \mu \mathrm{M} \mathrm{MSA}$ for 24 h; HIF-1a and HIF-2a were detected by western blot. $\beta$-actin expression was used as a loading control. (B) MSA down-regulates secreted VEGF in RC2 cells but not in 786-0 cells. Secreted VEGF was measured by ELISA in CCRCC cells. Cells were treated with and without MSA for $24 \mathrm{~h}$ and media were used to measure VEGF in RC2 and 786-0 cells and normalized with protein and expressed as pg/mg protein. Experiment was repeated twice with duplicates and P value $<0.05$ was considered as significant. (C). HIF-a inhibition by MSA was associated with growth inhibition. Cells were treated with various concentrations MSA $(3,5,7$ and $10 \mu \mathrm{M})$ for $24 \mathrm{~h}$. Medium was removed, rinsed and fresh medium was added and allowed to proliferate for $96 \mathrm{~h}$. Cells were fixed and determined the cell survival by SRB assay. Growth inhibition was presented as percent growth inhibition compared to untreated controls. Experiment was repeated twice with 4-5 replicate samples. ${ }^{*} p<0.001$. (D). VHL transfected RC2 cells which do not express HIF-1a were equally sensitive to MSA like RC2 cells which express HIF-1a. Expression of HIF-1a in RC2 and VHL transfected RC2 VHL cells with and without MSA (upper panel). Cytotoxic effects of MSA in RC2 and RC2 VHL cells (lower panel). Cell survival was determined by SRB assay. ${ }^{*} \mathrm{p}<0.001$.

in accumulation of HIF- $1 \alpha$, and this accumulated HIF- $1 \alpha$ was not removed by MSA in FaDu cells. In contrast, MSA treatment resulted in degradation of HIF- $1 \alpha$ independent of proteasome inhibitor MG132 in RC2 cells. These data suggest that degradation of HIF- $1 \alpha$ by MSA was proteasome dependent in $\mathrm{FaDu}$ cells but not in $\mathrm{RC} 2$ cells.

\section{Degradation of HIF-1 a by MSA is PHD2 dependent and VHL independent}

VHL is inactivated in several human ccRCC [1] and PHD3 is undetectable in all of the 88 ccRCC specimens tested (Figure 1C) and ccRCC cell lines (Figure 2D). To test the hypothesis that the degradation of HIF- $1 \alpha$ by MSA is PHD2 dependent, and VHL independent, two approaches were evaluated: i) treat with PHD2 activity inhibitor, DMOG alone and in combination with MSA (Figure 5A) and ii) treat with siRNA against PHD2 (Figure 5B) and VHL (Figure 5C) with the combination of MSA. Since RC2 and 786-0 cells express mutated VHL, we have used FaDu cells which express wild type VHL. HIF- $1 \alpha$ is not detectable in FaDu cells under normoxic culture conditions expressing PHD2 and PHD3
[22]. However, inhibition of PHDs activity by DMOG resulted in stable expression of HIF-1 $\alpha$. Treatment of MSA in combination with DMOG did not result in degradation of HIF- $1 \alpha$ in FaDu cells expressing PHD2/3 (Figure 5A). In support of these findings, MSA treatment leads to degradation of HIF- $1 \alpha$ in RC2 cells expressing PHD2 protein with nonfunctional VHL and this degradation is reversed in combination with DMOG (Figure 5A). Consistent with these findings, inhibition of PHD2 by siRNA did not resulted in the degradation of HIF- $1 \alpha$ by MSA in RC2 tumor cells expressing constitutive HIF-1 $\alpha$ with mutated VHL (Figure 5B). The data in Figure $5 \mathrm{C}$ demonstrated that inhibition of VHL by siRNA did not prevent HIF- $1 \alpha$ degradation by MSA in $\mathrm{FaDu}$ cells expressing functional VHL. Collectively, the data is consistent with the hypothesis that degradation of HIF- $1 \alpha$ by a pharmacological dose of MSA is PHD2 dependent, and VHL independent.

\section{Degradation of HIF-2 $a$ by MSC is associated with antitumor activity in 786-0 tumor xenografts}

To confirm that inhibition of HIF- $2 \alpha$ by a nontoxic dose of MSC will translate into therapeutic benefits, 786-0 


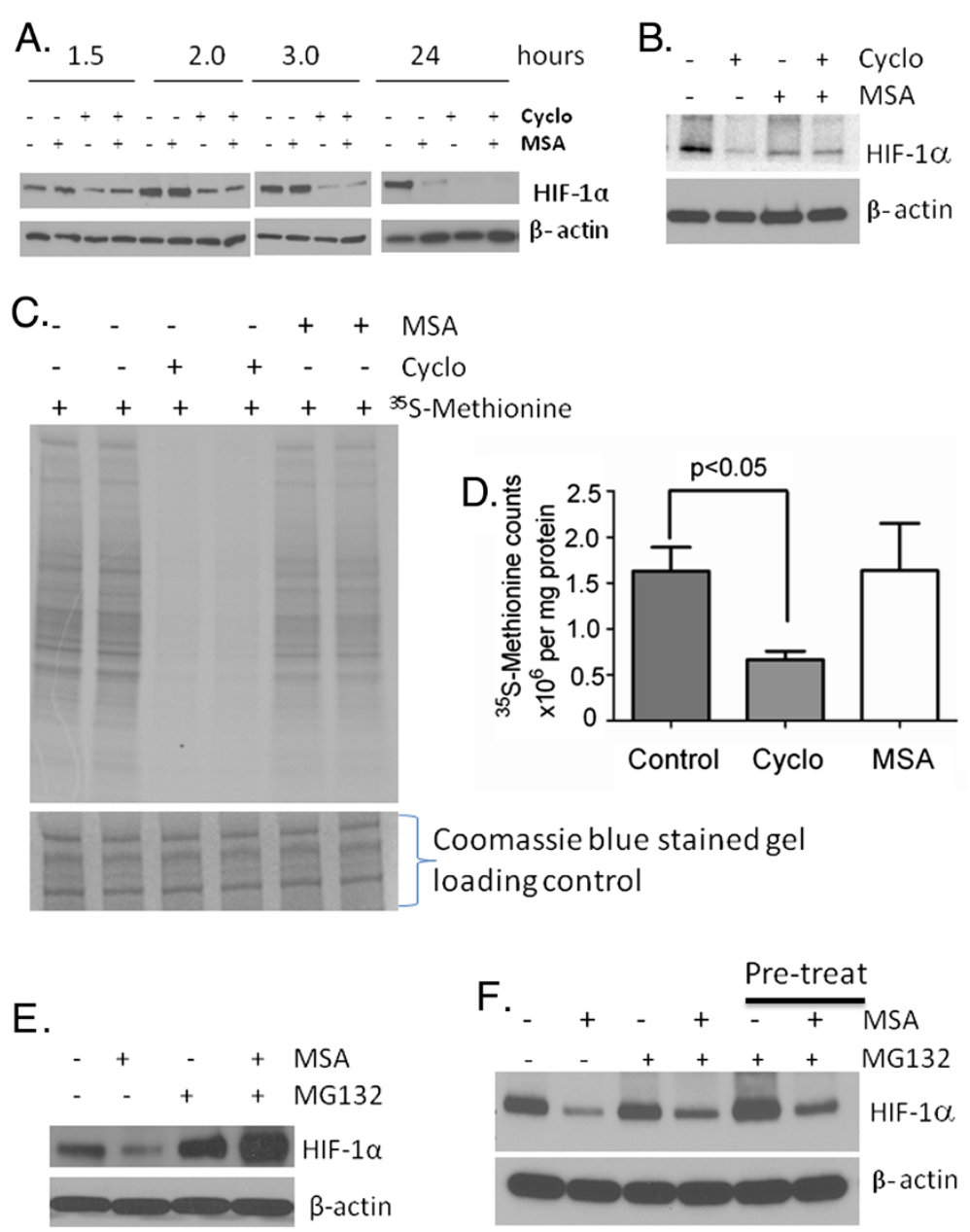

Figure 4 Effect of MSA on HIF-1a protein synthesis and degradation. (A) HIF-1a synthesis was inhibited by cycloheximide but not by MSA in FaDu cells. FaDu cells were treated with $1 \mu \mathrm{M} \mathrm{MSA}$ and $10 \mu \mathrm{M}$ cycloheximide alone and in combination for 1.5, 2, 3 and 24 hours at $0.5 \%$ oxygen and protein extracts were used to determine HIF-1a by western blot. $\beta$-actin expression was used as a loading control. (B) Effect of MSA on HIF-1a protein synthesis in RC2 cells. Cells were treated with cycloheximide or MSA alone and in combination for 8 h. HIF-1a was detected by western blot. $\beta$-actin was used as loading control (C) Incorporation of ${ }^{35} \mathrm{~S}$-Methionine was not affected by MSA in RC2. Cells were treated with cycloheximide or MSA separately in duplicate samples for $5 \mathrm{~h}$ and ${ }^{35} \mathrm{~S}$-Methionine $(2.3 \mu \mathrm{Cl} / \mathrm{ml})$ was added at the last $1 \mathrm{~h}$ of treatment. Protein extracts $(20 \mu \mathrm{g})$ were used to separate by SDS polyacrylamide gel electrophoresis and detected the incorporated ${ }^{35}$ S-Methionin by autoradiography. Lower panel showing the coomassie blue stained proteins as loading control. (D) Determination of ${ }^{35}$ S-Methionine radioactivity counts in cycloheximide or MSA treated RC2 cells. Protein extracts $(20 \mu \mathrm{l})$ were used to detect ${ }^{35} \mathrm{~S}$-methionine radioactivity in the cells by counting in Liquid Scientilator Counter. Total counts were calculated in one milligram of protein and presented the number of counts in millions as compared to untreated control cells. P $<0.05$ was considered as significant. (E) HIF-1a degradation by MSA is proteasome dependent. FaDu cells which do not express constitutive HIF-1a under normoxic culture conditions were subjected to $0.5 \%$ oxygen and treated with $1 \mu \mathrm{M}$ MSA alone and in combination with $10 \mu \mathrm{M}$ proteasome inhibitor MG132 for $24 \mathrm{~h}$. Cell extracts were prepared and the expression of HIF-I a was analyzed. Expression of $\beta$-actin was used as a loading control. (F) Proteasome independent degradation of HIF-1a in VHL mutated RC2 cells. RC2 cells were treated with MSA and MG132 alone and in combination for $8 \mathrm{~h}$. In a separate experiment, $1 \mathrm{~h}$ pre-treatment of MG132 followed by $7 \mathrm{~h} \mathrm{MSA}$ treatment was performed to see the effect of MSA on HIF-1a. Cells were processed to extract protein and HIF-1a levels were determined. Expression of $\beta$-actin was used as a loading control.

xenografts expressing constitutively active HIF- $2 \alpha$ were treated orally daily with $0.2 \mathrm{mg} / \mathrm{mouse} /$ day $\mathrm{MSC}$ for 18 days. The data presented in Figure 6 showed that MSC treatment resulted in significant inhibition of tumor growth (Figure 6A) which was associated with inhibition of HIF-2 $\alpha$ (Figure 6B). These data are consistent with the previous finding from this laboratory demonstrating that the inhibition of HIF- $1 \alpha$ by MSC resulted in significant antitumor activity against FaDu tumor xenografts [22].

\section{Discussion}

The expression of PHD2/3, the main regulators of HIF- $\alpha$ has not been investigated in primary human ccRCC using double immunohistochemical staining to detect 


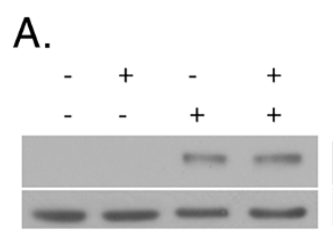

$\mathrm{FaDu}$

C.

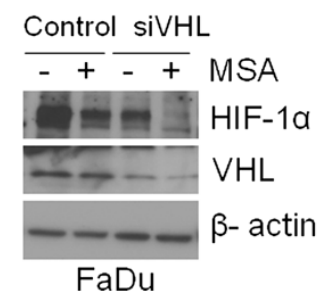

B.

Control siPHD2

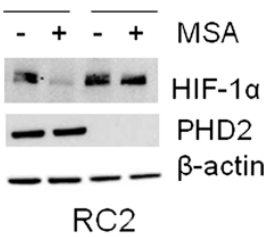

Figure 5 Role of PHDs in HIF-1a degradation by MSA. (A) Inhibition of PHDs activity by DMOG reversed the degradation of HIF-1a by MSA in VHL active FaDu, and VHL inactive RC2 cells. Cells were treated with $10 \mu \mathrm{M}$ MSA and 0.5 mM DMOG alone and in combination and HIF-1a was analyzed by western blot. $\beta$-actin expression was used as a loading control. (B) Gene specific silencing of PHD2 in RC2 cells by siRNA prevented the degradation of HIF-1a by MSA. PHD2 siRNA was transfected with lipofectamine 2000 for $24 \mathrm{~h}$. Cells were treated with and without $10 \mu \mathrm{M}$ MSA for $24 \mathrm{~h}$ and HIF-1a was detected by western blot. $\beta$-actin expression was used as a loading control. (C) Degradation of HIF-1a by MSA is VHL independent. VHL was inhibited by siRNA in FaDu cells expressing active VHL and treated with MSA to determine the HIF-1a degradation. This experiment was done under $0.5 \%$ oxygen level to stabilize HIF-1a in FaDu cells. $\beta$-actin expression was used as a loading control.

these proteins simultaneously in consecutive sections of the same tumors. In this study, we have demonstrated low incidence, distribution and staining intensity of PHD2, deficient PHD3 protein, and high HIF- $\alpha$ incidence, distribution and intensity in 88 primary ccRCC cancers compared to head \& neck and colorectal cancers (Figure 1A, B and C). Furthermore, like clinical samples, the two ccRCC cell lines (RC2 and 786-0) used for mechanistic studies were deficient in PHD3 protein (Figure 2D) but not mRNA (Figure 2B). The high incidence of HIF- $\alpha$ in ccRCC has been partially linked to the mutation of VHL gene. The VHL gene mutation incidence varies from 19.6 to $89.4 \%$ in ccRCC $[32,33]$ and the majority of reports show 30-60\% mutation incidence [34]. Furthermore, the up-regulation of both HIF-1 $\alpha$ (88.2\%) and HIF-2 $\alpha$ (100\%) with only $39.1 \%$ VHL mutations was found in ccRCC showing the VHL independent upregulation of HIF- $\alpha$ in many cases [34]. Our results suggest a role for PHD2/3 in addition to the well documented VHL mutations in the constitutive expression of HIF- $\alpha$ in

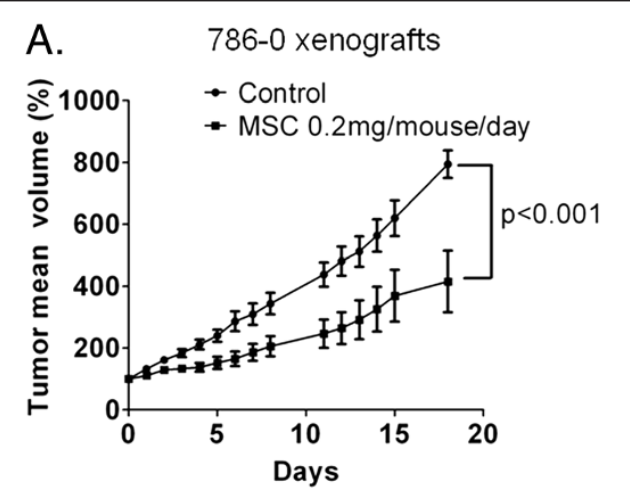

B.

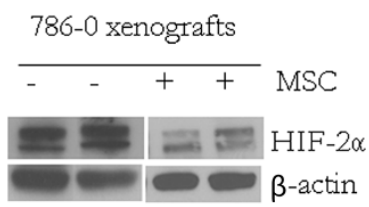

Figure 6 MSC effect on tumor growth and HIF-2a expression in 786-0 ccRCC xenografts. (A) Inhibition of cCRCC tumor growth by MSC in xenografts. HIF-2a expressing 786-0 cells (10 million) were transplanted into nude mice for establishing the xenografts. Small pieces ( 50 mg) of tumor tissues were transplanted subcutaneously into nude mice and treatment began when tumor weighed $200-250$ mg. Mice were

randomized and divided into two groups, each containing 5 mice. One group was treated with saline and the other group was treated with MSC ( $0.2 \mathrm{mg} / \mathrm{mouse} /$ day; the optimal nontoxic dose) daily for 18 days. Tumor volume was measured daily. (B) HIF-2a is inhibited by the therapeutic dose of MSC in 786-0 xenografts. Tumor xenografts collected after 18 days of the MSC treatments and processed to extract protein and HIF-2a levels were assessed by western blot. $\beta$-actin expression was used as a loading control. 
ccRCC. A recent report showed the silencing of PHD3 expression by $\mathrm{CpG}$ methylation in the promoter region of human cancer cell lines including renal cancer, prostate, breast and melanoma [12], and in plasma cells and B-cell lymphoma, suggesting PHD3 as a potential biomarker [35]. In addition, Astuli et al., [36] found the absence of pathogenic mutations in PHD1, 2 and 3 that could cause renal cell carcinoma. Our western blot analysis showed very weak expression of PHD3 protein compared to PHD2 (Figure 2C) in two representative primary tumor cases. This weak signal may be derived from the normal stromal cells expressing PHD3 [9]. These results suggest that there may be some epigenetic regulation of PHD3 expression in ccRCC that might lead to the degradation or inhibition of PHD3 protein. A recent clinical study showed a positive correlation between decreased PHD3 expression and aggressive type of breast tumors [37]. Similarly, the lack of expression or low incidence/intensity of PHD3 may contribute to the aggressiveness of ccRCC tumors. Thus, the agents that enhance HIF- $\alpha$ degradation by PHD2, independent of PHD3 expression may offer treatment modality that could affect resistance and clinical outcome.

This laboratory is the first to show that therapeutic dose of selenium as highly effective inhibitor of both constitutively expressed HIF- $1 \alpha$, HIF- $2 \alpha$ in ccRCC (Figure $3 \mathrm{~A}$ and $6 \mathrm{~B}$ ) and hypoxia induced HIF-1 $\alpha$ in head $\&$ neck cancer [22]. Consistent with our data, published results show the degradation of constitutively expressed HIF-1 $\alpha$ in prostate cancer [38] and hypoxia induced HIF-1 $\alpha$ in B-cell lymphoma [39] by selenium. These findings show that both hypoxia induced and constitutively expressed HIF- $\alpha$ are inhibited by selenium suggesting that selenium could inhibit growth of tumors expressing HIF- $1 \alpha$, HIF- $2 \alpha$ or both. HIF- $\alpha$ transcriptionally regulated gene, VEGF, is regulated by MSA in renal cancer cells (Figure 3B). MSA treatment leads to the down-regulation of secreted VEGF in HIF-1 $\alpha$ expressing RC2. The lack of MSA effects on secreted VEGF in 786- 0 cells could be due to low levels of secreted VEGF in these cells. To our surprise we did not see difference in cytotoxic effects of MSA in RC2 and RC2VHL cells even though there is a marked difference in HIF- $1 \alpha$ levels in these cells under normoxic culture conditions. This may be due to the other effects of MSA in these particular cells with VHL transfection. VHL being a multifunctional adaptor molecule involved in the inhibition of HIF- $\alpha$ independent and dependent cellular processes [40]. The cytotoxic effects of MSA in RC2VHL cells may be through VHL interacting proteins. Our data demonstrate that selenium main target HIF- $\alpha$ is degraded by PHD dependent and VHL independent, but some of our unexpected findings with VHL transfected RC2 cells indicate that VHL transfection may influence the cytotoxic effects of MSA independent of HIF- $1 \alpha$ by currently unclear molecular mechanism.

We have demonstrated HIF- $\alpha$ inhibition by selenium as a post-translational degradation mechanism. As shown in the Figure 4A and B, MSA did not affect HIF$\alpha$ protein synthesis. In a separate experiment, we have demonstrated that the overall protein synthesis was not altered by MSA using the ${ }^{35} \mathrm{~S}$-Methionine incorporation studies (Figure $4 \mathrm{C}$ and D). The proteasome inhibitor MG132 reversed the degradation of HIF- $\alpha$ by MSA in $\mathrm{FaDu}$ cells (Figure 4E) demonstrating the proteasome dependent degradation. In contrast, in RC2 cells proteasome inhibition did not reverse the degradation of HIF- $1 \alpha$ by MSA suggest that in VHL mutant cells MSA may be degrading HIF-1 $\alpha$ through proteasome independent pathway. Further detailed mechanistic studies need to be performed to investigate how MSA is degrading HIF- $\alpha$ in the absence of VHL in ccRCC. Our results also show that MSA is unable to degrade HIF- $1 \alpha$ stabilized by DMOG, an inhibitor of PHDs activity (Figure 5A). DMOG inhibits PHD activity by competing with 2-oxoglutarate, a cofactor for PHDs activity. In addition, gene specific inhibition of PHD2 also prevented the degradation of HIF- $1 \alpha$ by MSA (Figure 5B). Furthermore, we have confirmed VHL independent degradation of HIF- $1 \alpha$ by silencing of VHL with siRNA in VHL positive FaDu cells (Figure 5C). As reported in the literature, VHL knockdown did not lead an increase of HIF$1 \alpha$ in $\mathrm{FaDu}$ cells under hypoxic conditions [41]. These results indicate that selenium utilizes a unique pathway for HIF-1 $\alpha$ degradation through PHD2 dependent and VHL independent degradation mechanism. Future studies are warranted to investigate specific function of PHD2 that might be altered by selenium leading to the degradation of HIF- $\alpha$ through another ligase independent of VHL.

Our recent report [22] and study by Sinha et al., [38] demonstrated stabilization of PHDs by MSA leads to the degradation of HIF- $1 \alpha$. HIF- $1 \alpha$ degradation through VHL dependent and independent pathways is known. Under aerobic conditions, HIF- $1 \alpha$ is hydroxylated at 402 and 564 proline molecules by PHDs and recognized by VHL and further degraded by proteasome [42,43]. HIF$1 \alpha$ is also degraded without PHD through a small ubiquitin-like modifier (SUMO)ylation that allows the binding of VHL to further degrade HIF- $1 \alpha$ by proteasome [44]. There has been growing evidence for VHL independent degradation of HIF-1 $\alpha$ through histone deacetylases (HDACs) inhibition [28,39], heat shock protein 90 (HSP90) $[45,46]$, the hypoxia associated factor (HAF) [47] and an undescribed cullin-independent proteasome degradation pathway $[29,48]$.

Based on the demonstrated low incidence of PHD2, lack of PHD3 protein and high incidence of HIF- $\alpha$ in ccRCC, we expect that HIF- $\alpha$ mediated drug resistance 
is particularly important in this type of cancer. Therefore, decreasing HIF- $\alpha$ expression in ccRCC cells seems to be an important new strategy in order to sensitize tumor cells to the currently used standard therapy. We found MSA treatment lead to 786-0 tumor growth inhibition which correlated with reduced HIF- $2 \alpha$ protein levels (Figure 6). It is important to indicate that although HIF- $1 \alpha$ role in drug resistance has been widely evaluated [49], to date, efforts have been focused on the development of agents that would effectively inhibit HIF- $1 \alpha$ synthesis [50-52]. MSC represents a new type of HIF- $\alpha$ inhibitor by enhancing the degradation, but not affecting the synthesis of HIF- $\alpha$. Currently, it is difficult to predict what approach of HIF- $\alpha$ inhibition combined with chemotherapy will improve the cancer therapy. Furthermore, utilization of clinically more relevant orthotopic imageable mouse models [53-55] would be more appropriate for further development of MSC as HIF- $\alpha$ inhibitor in ccRCC.

\section{Conclusions}

We have demonstrated that low incidence of PHD2 and deficiency of PHD3 protein associated with high incidence of HIF- $\alpha$ in ccRCC. Both HIF- $1 \alpha$ and HIF- $2 \alpha$ are inhibited by MSC through PHD2 dependent and VHL independent degradation mechanism. Furthermore, HIF- $2 \alpha$ degradation by MSC leads to inhibition of the growth of ccRCC tumor xenografts without toxicity. Thus, our data supports further evaluation of MSC as a HIF- $\alpha$ inhibitor in combination with multikinase inhibitors, like sunitinib, to determine their efficacy in ccRCC xenograft model.

\section{Abbreviations \\ CCRCC: Clear cell renal cell carcinoma; HIF-1a: Hypoxia inducible factor-1 alpha; HIF-2a: Hypoxia inducible factor 2 alpha; HIF-a: HIF-1a and HIF-2a; PHD: Prolyl hydroxylase; VHL: Von-Hippel-Lindau; VEGF: Vascular endothelial growth factor; SiRNA: Small interfering RNA; MSC: Se-Methylselenocysteine; MSA: Methylselenic acid; DMOG: Dimethyloxallyl glycine; MG132: N- [(phenylmethoxy)carbonyl]-L-leucyl-N-[(1 S)-1-formyl-3-methylbutyl]-L- leucinamide; TMA: Tissue microarray; DBBR: Data bank and bioRepository; EGLN1: Egg-laying-defective nine1.}

\section{Competing interests}

The authors declare that they have no competing interests.

\section{Authors' contributions}

SC: Conception, design and collection of data, manuscript writing, data analysis and interpretation. TB: Design, collection, analysis and interpretation of in vitro data. KT: Analysis and interpretation of TMAs immunohistochemical data. SC and FAD: Collection, analysis and interpretation of animal experiments data. RP: Provision of patients samples, analysis and interpretation of data. YMR: Conception, design, and manuscript writing. All authors read and approved the final manuscript.

\section{Acknowledgements}

We acknowledge the Pathology Core facility for providing human primary tumor specimens including TMAs and Genomic Shared Resources for gene expression assay at Roswell Park Cancer Institute. We thank Dr. Austin Miller for statistical analysis of the data. These studies were supported in part by National Cancer Institute grants CA 133682 (S. Chintala) and Roswell Park Cancer Institute's Comprehensive Cancer Center Support Grant CA16056.

\section{Author details}

'Department of Cancer Biology, Roswell Park Cancer Institute, Buffalo, NY 14263, USA. ²Department of Medicine, Roswell Park Cancer Institute, Buffalo, New York 14263, USA. ${ }^{3}$ Department of Pharmacology \& Therapeutics,

Roswell Park Cancer Institute, Buffalo, NY 14263, USA.

Received: 28 November 2011 Accepted: 27 June 2012

Published: 17 July 2012

\section{References}

1. Linehan WM, Srinivasan R, Schmidt LS: The genetic basis of kidney cancer: a metabolic disease. Nature reviews 2010, 7(5):277-285

2. US National Institutes of Health: Institute N.C. kidney cancer [online]. 2010, http://www.cancer.gov/cancertopics/types/kidney.

3. Hervouet E, Demont J, Pecina P, Vojtiskova A, Houstek J, Simonnet H, Godinot C: A new role for the von Hippel-Lindau tumor suppressor protein: stimulation of mitochondrial oxidative phosphorylation complex biogenesis. Carcinogenesis 2005, 26(3):531-539.

4. Semenza GL: Targeting HIF-1 for cancer therapy. Nat Rev Cancer 2003, 3(10):721-732

5. Chan DA, Kawahara TL, Sutphin PD, Chang HY, Chi JT, Giaccia AJ: Tumor vasculature is regulated by PHD2-mediated angiogenesis and bone marrow-derived cell recruitment. Cancer Cell 2009, 15(6):527-538.

6. Chan DA, Giaccia AJ: PHD2 in tumour angiogenesis. Br J Cancer 2010, 103(1):5.

7. Appelhoff RJ, Tian YM, Raval RR, Turley H, Harris AL, Pugh CW, Ratcliffe PJ, Gleadle JM: Differential function of the prolyl hydroxylases PHD1, PHD2, and PHD3 in the regulation of hypoxia-inducible factor. The J biological chemistry 2004, 279(37):38458-38465.

8. Bruick RK, McKnight SL: A conserved family of prolyl-4-hydroxylases that modify HIF. Science 2001, 294(5545):1337-1340.

9. Soilleux EJ, Turley H, Tian YM, Pugh CW, Gatter KC, Harris AL: Use of novel monoclonal antibodies to determine the expression and distribution of the hypoxia regulatory factors PHD-1, PHD-2, PHD-3 and FIH in normal and neoplastic human tissues. Histopathology 2005, 47(6):602-610.

10. Wenger RH, Camenisch G, Stiehl DP, Katschinski DM: HIF prolyl4-hydroxylase interacting proteins: consequences for drug targeting. Curr Pharm Des 2009, 15(33):3886-3894.

11. Metzen E, Berchner-Pfannschmidt U, Stengel $P$, Marxsen JH, Stolze I, Klinger M, Huang WQ, Wotzlaw C, Hellwig-Burgel T, Jelkmann W, et al: Intracellular localisation of human HIF-1 alpha hydroxylases: implications for oxygen sensing. J Cell Sci 2003, 116(Pt 7):1319-1326.

12. Place TL, Fitzgerald MP, Venkataraman S, Vorrink SU, Case AJ, Teoh ML, Domann FE: Aberrant promoter CpG methylation is a mechanism for impaired PHD3 expression in a diverse set of malignant cells. PLoS One 2011, 6(1):e14617.

13. Liu Y, Huo Z, Yan B, Lin $X$, Zhou ZN, Liang $X$, Zhu W, Liang D, Li L, Zhao $\mathrm{H}$, et al: Prolyl hydroxylase 3 interacts with $\mathrm{Bcl}-2$ to regulate doxorubicin-induced apoptosis in $\mathrm{H} 9 \mathrm{c} 2$ cells. Biochem Biophys Res Commun 2010, 401(2):231-237.

14. Tennant DA, Gottlieb E: HIF prolyl hydroxylase-3 mediates alphaketoglutarate-induced apoptosis and tumor suppression. $J$ Mol Med (Berl) 2010, 88(8):839-849.

15. Pan Y, Mansfield KD, Bertozzi CC, Rudenko V, Chan DA, Giaccia AJ, Simon MC: Multiple factors affecting cellular redox status and energy metabolism modulate hypoxia-inducible factor prolyl hydroxylase activity in vivo and in vitro. Mol Cell Biol 2007, 27(3):912-925.

16. Metzen E, Zhou J, Jelkmann W, Fandrey J, Brune B: Nitric oxide impairs normoxic degradation of HIF-1alpha by inhibition of prolyl hydroxylases. Molecular biology of the cell 2003, 14(8):3470-3481.

17. Chowdhury R, Flashman E, Mecinovic J, Kramer HB, Kessler BM, Frapart YM Boucher JL, Clifton IJ, McDonough MA, Schofield CJ: Studies on the reaction of nitric oxide with the hypoxia-inducible factor prolyl hydroxylase domain 2 (EGLN1). J molecular biology 2011, 410(2):268-279.

18. Finley LW, Carracedo A, Lee J, Souza A, Egia A, Zhang J, Teruya-Feldstein J, Moreira PI, Cardoso SM, Clish CB, et al: SIRT3 opposes reprogramming of cancer cell metabolism through HIF1alpha destabilization. Cancer Cell 2011, 19(3):416-428.

19. Sun M, Lughezzani G, Perrotte P, Karakiewicz PI: Treatment of metastatic renal cell carcinoma. Nat Rev Urol 2010, 7(6):327-338. 
20. Rapisarda A, Shoemaker RH, Melillo G: Antiangiogenic agents and HIF-1 inhibitors meet at the crossroads. Cell Cycle 2009, 8(24):4040-4043.

21. Lippman SM, Klein EA, Goodman PJ, Lucia MS, Thompson IM, Ford LG, Parnes HL, Minasian LM, Gaziano JM, Hartline JA, et al: Effect of selenium and vitamin $E$ on risk of prostate cancer and other cancers: the Selenium and Vitamin E Cancer Prevention Trial (SELECT). JAMA 2009, 301(1):39-51.

22. Chintala S, Toth K, Cao S, Durrani FA, Vaughan MM, Jensen RL, Rustum YM: Se-methylselenocysteine sensitizes hypoxic tumor cells to irinotecan by targeting hypoxia-inducible factor 1alpha. Cancer Chemother Pharmacol 2010, 66(5):899-911.

23. Yin MB, Li ZR, Toth K, Cao S, Durrani FA, Hapke G, Bhattacharya A, Azrak RG, Frank C, Rustum YM: Potentiation of irinotecan sensitivity by Semethylselenocysteine in an in vivo tumor model is associated with downregulation of cyclooxygenase-2, inducible nitric oxide synthase, and hypoxia-inducible factor 1 alpha expression, resulting in reduced angiogenesis. Oncogene 2006, 25(17):2509-2519.

24. Bhattacharya A, Seshadri M, Oven SD, Toth K, Vaughan MM, Rustum YM: Tumor vascular maturation and improved drug delivery induced by methylselenocysteine leads to therapeutic synergy with anticancer drugs. Clin Cancer Res 2008, 14(12):3926-3932.

25. Cao S, Durrani FA, Rustum YM: Selective modulation of the therapeutic efficacy of anticancer drugs by selenium containing compounds against human tumor xenografts. Clin Cancer Res 2004 10(7):2561-2569.

26. Kessler J, Hahnel A, Wichmann H, Rot S, Kappler M, Bache M, Vordermark D: HIF-1alpha inhibition by siRNA or chetomin in human malignant glioma cells: effects on hypoxic radioresistance and monitoring via CA9 expression. BMC Cancer 2010, 10:605.

27. Vaughan MM, Toth $K$, Chintala S, Rustum YM: Double Immunohistochemical Staining Method for HIF-1alpha and its Regulators PHD2 and PHD3 in Formalin-fixed Paraffin-embedded Tissues. Appl Immunohistochem Mol Morphol 2010, 18(4):375-381.

28. Qian DZ, Kachhap SK, Collis SJ, Verheul HM, Carducci MA, Atadja P Pili R: Class II histone deacetylases are associated with VHLindependent regulation of hypoxia-inducible factor 1 alpha. Cancer Res 2006, 66(17):8814-8821.

29. Kong HS, Lee S, Beebe K, Scroggins B, Gupta G, Lee MJ, Jung YJ, Trepel J, Neckers $L$ : Emetine promotes von Hippel-Lindau-independent degradation of hypoxia-inducible factor-2alpha in clear cell renal carcinoma. Mol Pharmacol 2010, 78(6):1072-1078.

30. Chintala S, Tan J, Gautam R, Rusiniak ME, Guo X, Li W, Gahl WA, Huizing M, Spritz RA, Hutton S, et al: The Slc35d3 gene, encoding an orphan nucleotide sugar transporter, regulates platelet-dense granules. Blood 2007, 109(4):1533-1540.

31. Agresti A, Coull BA: Approximate is better than exact for interval estimation of binomial proportions. The Am Statistician 1998, 52(2):119-126.

32. Gordan JD, Lal P, Dondeti VR, Letrero R, Parekh KN, Oquendo CE, Greenberg RA, Flaherty KT, Rathmell WK, Keith B, et al: HIF-alpha effects on c-Myc distinguish two subtypes of sporadic VHL-deficient clear cell renal carcinoma. Cancer Cell 2008, 14(6):435-446.

33. Kim JH, Jung CW, Cho YH, Lee J, Lee SH, Kim HY, Park J, Park JO, Kim K, Kim WS, et al: Somatic VHL alteration and its impact on prognosis in patients with clear cell renal cell carcinoma. Oncology reports 2005, 13(5):859-864.

34. Nyhan MJ, El Mashad SM, O'Donovan TR, Ahmad S, Collins C, Sweeney P, Rogers E, O'Sullivan GC, McKenna SL: VHL genetic alteration in CCRCC does not determine de-regulation of HIF, CAIX, hnRNP A2/B1 and osteopontin. Anal Cell Pathol (Amst) 2010, 33(3):121-132.

35. Hatzimichael E, Dasoula A, Shah R, Syed N, Papoudou-Bai A, Coley HM, Dranitsaris G, Bourantas KL, Stebbing J, Crook T: The prolyl-hydroxylase EGLN3 and not EGLN1 is inactivated by methylation in plasma cell neoplasia. European J haematology 2010, 84(1):47-51.

36. Astuti D, Ricketts CJ, Chowdhury R, McDonough MA, Gentle D, Kirby G, Schlisio S, Kenchappa RS, Carter BD, Kaelin WG Jr, et al: Mutation analysis of HIF prolyl hydroxylases (PHD/EGLN) in individuals with features of phaeochromocytoma and renal cell carcinoma susceptibility. Endocrinerelated cancer 2011, 18(1):73-83.

37. Yan M, Rayoo M, Takano EA, Fox SB: BRCA1 tumours correlate with a HIF-1alpha phenotype and have a poor prognosis through modulation of hydroxylase enzyme profile expression. $\mathrm{Br} J$ Cancer 2009, 101(7):1168-1174.
38. Sinha I, Null K, Wolter W, Suckow MA, King T, Pinto JT, Sinha R: Methylseleninic acid down regulates hypoxia inducible factor-1alpha in invasive prostate cancer. Int J cancer 2012, 130(6):1430-1439.

39. Kassam S, Goenaga-Infante H, Maharaj L, Hiley CT, Juliger S, Joel SP: Methylseleninic acid inhibits HDAC activity in diffuse large B-cell lymphoma cell lines. Cancer Chemother Pharmacol 2011, 68(3):815-821.

40. Cai Q, Verma SC, Kumar P, Ma M, Robertson ES: Hypoxia inactivates the VHL tumor suppressor through PIASy-mediated SUMO modification. PLoS One 2010, 5(3):e9720.

41. To KK, Huang LE: Suppression of hypoxia-inducible factor 1alpha (HIF1alpha) transcriptional activity by the HIF prolyl hydroxylase EGLN1. The Journal of biological chemistry 2005, 280(45):38102-38107.

42. Maxwell PH, Wiesener MS, Chang GW, Clifford SC, Vaux EC, Cockman ME, Wykoff CC, Pugh CW, Maher ER, Ratcliffe PJ: The tumour suppressor protein VHL targets hypoxia-inducible factors for oxygen-dependent proteolysis. Nature 1999, 399(6733):271-275.

43. Ohh M, Park CW, Ivan M, Hoffman MA, Kim TY, Huang LE, Pavletich N, Chau $V$, Kaelin WG: Ubiquitination of hypoxia-inducible factor requires direct binding to the beta-domain of the von Hippel-Lindau protein. Nat Cell Biol 2000, 2(7):423-427.

44. Cheng J, Kang X, Zhang S, Yeh ET: SUMO-specific protease 1 is essential for stabilization of HIF1alpha during hypoxia. Cell 2007, 131(3):584-595.

45. Liu YV, Baek JH, Zhang H, Diez R, Cole RN, Semenza GL: RACK1 competes with HSP90 for binding to HIF-1alpha and is required for $\mathrm{O}(2)-$ independent and HSP90 inhibitor-induced degradation of HIF-1alpha. Mol Cell 2007, 25(2):207-217.

46. Isaacs JS, Jung YJ, Mimnaugh EG, Martinez A, Cuttitta F, Neckers LM: Hsp90 regulates a von Hippel Lindau-independent hypoxiainducible factor-1 alpha-degradative pathway. The J biological chem 2002, 277(33):29936-29944.

47. Koh MY, Darnay BG, Powis G: Hypoxia-associated factor, a novel E3-ubiquitin ligase, binds and ubiquitinates hypoxia-inducible factor 1 alpha, leading to its oxygen-independent degradation. Mol Cell Biol 2008, 28(23):7081-7095.

48. Zhou YD, Kim YP, Mohammed KA, Jones DK, Muhammad I, Dunbar DC, Nagle DG: Terpenoid tetrahydroisoquinoline alkaloids emetine, klugine, and isocephaeline inhibit the activation of hypoxia-inducible factor-1 in breast tumor cells. J Nat Prod 2005, 68(6):947-950.

49. Semenza GL: HIF-1 inhibitors for cancer therapy: from gene expression to drug discovery. Curr Pharm Des 2009, 15(33):3839-3843.

50. Zhang H, Qian DZ, Tan YS, Lee K, Gao P, Ren YR, Rey S, Hammers H, Chang D, Pili $R$, et al: Digoxin and other cardiac glycosides inhibit HIF-1alpha synthesis and block tumor growth. Proc Natl Acad Sci USA 2008, 105(50):19579-19586.

51. Rapisarda A, Uranchimeg B, Sordet O, Pommier $Y$, Shoemaker RH, Melillo G: Topoisomerase I-mediated inhibition of hypoxia-inducible factor 1: mechanism and therapeutic implications. Cancer Res 2004, 64(4):1475-1482.

52. Patiar S, Harris AL: Role of hypoxia-inducible factor-1alpha as a cancer therapy target. Endocr Relat Cancer 2006, 13(Suppl 1):S61-75.

53. An Z, Jiang P, Wang X, Moossa AR, Hoffman RM: Development of a high metastatic orthotopic model of human renal cell carcinoma in nude mice: benefits of fragment implantation compared to cell-suspension injection. Clin Exp Metastasis 1999, 17(3):265-270.

54. Hoffman RM: Orthotopic metastatic mouse models for anticancer drug discovery and evaluation: a bridge to the clinic. Invest New Drugs 1999, 17 (4):343-359.

55. Hoffman RM: The multiple uses of fluorescent proteins to visualize cancer in vivo. Nat Rev Cancer 2005, 5(10):796-806.

doi:10.1186/1471-2407-12-293

Cite this article as: Chintala et al:: Prolyl hydroxylase 2 dependent and Von-Hippel-Lindau independent degradation of Hypoxia-inducible factor 1 and 2 alpha by selenium in clear cell renal cell carcinoma leads to tumor growth inhibition. BMC Cancer 2012 12:293. 